\title{
Menengiç ve tespih çalısının mevsimlere ve otlanan bitki kısımlarına göre yem kalitesinin belirlenmesi
}

\section{Determination of nutritional value of terebinth and styrax tree according to the grazed plant parts and seasons}

\author{
Hasan DÖKÜLGEN ${ }^{1}$ iD, Süleyman TEMEL ${ }^{* 2}$ iD \\ ${ }^{1}$ Kilis III Tarım ve Orman Müdürlüğü, 79000, Kilis, Türkiye \\ ${ }^{2}$ Iğdır Üniversitesi Ziraat Fakültesi Tarla Bitkileri Bölümü, 76000, Iğdır, Türkiye
}

\section{To cite this article:}

Dökülgen, H. \& Temel, S. (2019). Menengiç ve tespih çalısının mevsimlere ve otlanan bitki kısımlarına göre yem kalitesinin belirlenmesi. Harran Tarım ve Gıda Bilimleri Dergisi, 23(2):178-188. DOI: 10.29050/harranziraat.425602

Address for Correspondence: Süleyman TEMEL e-mail:

stemel33@hotmail.com
Received Date:

21.05.2018

Accepted Date:

12.10.2018 (c) Copyright 2018 by Harran University Faculty of Agriculture. Available on-line at www.dergipark.gov.tr/harranziraat öz

Akdeniz bölgesi kırsal kesimde yaşayan halkın en önemli geçim kaynaklarından biri küçükbaş hayvan yetiştiriciliğidir. Bu coğrafyada yetişen pek çok çalı ve ağaç türleri ruminatlar için önemli yem kaynağı durumundadır. Diğer taraftan otlayan hayvanlardan maksimum performans elde edebilmek için tercih edilen türlerin otlatma zamanı ve kapasitesinin doğru bir şekilde belirlenmesi gerekmektedir. Bunu sağlamanın yollarından bir tanesi otlanan çalı ve ağaç türlerin mevsimlere göre yem kalite özelliklerinin belirlenmesidir. Ayrıca küçükbaş hayvanlar otlarken çalı türlerinin sadece yapraklarını değil, ince sürgün+yapraklarını da birlikte otlamaktadırlar. Bu bilgiler ışığında 2014 yılında Menengiç (Pistacia terebinthus L.)ve Tespih çalısı (Styrax officinalis L.)'nın yaprak ve yaprak + sürgünlerin ilkbahar, yaz ve sonbahar dönemlerindeki besin içeriğini ortaya koymak için bu çalışma planlanmıştır. Araştırma Kilis makiliklerinde, tesadüf bloklarında faktöriyel düzenlemeye göre, 4 tekrarlamalı olarak kurulmuş ve bitki örneklerinde; HP, NDF, ADF, ADL, KMS, SE, ME ve NYD belirlenmiştir. Analiz sonuçlarına göre; yem tipleri arasında (HP, NDF ve NYD hariç) incelemeye alınan besin değerleri önemsiz bulunurken, türler (HP hariç) ve dönemler arasında, önemli farklılıklar görülmüştür. Türler arasında tespih çalısının, menengiç bitkisine göre daha yüksek yem kalitesine sahip olduğu belirlenmiştir. En yüksek yem değeri, ilkbaharda belirlenmiş ve bunu sırasıyla yaz ve sonbahar dönemleri takip etmiştir. Otlanan kısımlar açısından yapraklar, yaprak+sürgünlerden daha yüksek HP ve NYD, daha düşük NDF oranına sahip olmuştur. Sonuç olarak, ilave bir yem takviyesine gerek duyulmadan, her iki türün, ilkbahar ve yaz dönemlerinde otlatılmasının uygun olduğu belirlenmiştir. Ayrıca, çalıların sadece yapraklarını otlayan hayvanların daha yüksek bir hayvansal performansa ulaşabileceği ortaya konmuştur.

Anahtar Kelimeler: Yaprağını döken çalılar, Otlatma zamanı, Besin değerleri, Küçükbaş hayvanlar

\section{ABSTRACT}

Small ruminant breeding is one of the most important sources of livelihood in rural areas of the Mediterranean region. Many shrubs in this region are important feed sources for ruminants. On the other hand, in order to obtain maximum performance from grazing livestock, grazing time and capacity should be determined correctly. One of the ways of achieving this is to determine the feed value of grazing species according to seasons. In addition, the small ruminants graze not only the leaves of shrub species, but also shoot+leaves together. For this purpose, a study was planned to reveal the nutritional content of leaf and leaf+shoots of Terebinth (Pistacia terebinthus L.) and Styrax Tree (Styrax officinalis L.) in spring, summer and autumn periods in 2014. Research was established according to randomized blocks factorial experimental design with four replications in Kilis Maqius and $\mathrm{CP}$, $\mathrm{NDF}, \mathrm{ADF}, \mathrm{ADL}, \mathrm{DMD}, \mathrm{DE}, \mathrm{ME}$ and RFV were investigated in fodder samples. According to results; the examined nutritional values were found significant between species (except CP) 
and seasons, but insignificant between feed types (except CP, NDF and RFV). Among species, it was determined that Styrax Tree had higher feed quality than Terebinth. The highest feed value was determined in spring, followed by summer and autumn. Leaves had higher HP and NYD, and lower NDF than leaf+shoots. Consequently, it was determined that both species were suitable for grazing in spring and summer periods without needing an additional feed supplementation. It was also revealed that animals grazing only leaves could attain a higher animal performance.

Key Words: Deciduous shrubs, Grazing time, Nutritional value, Small ruminants

\section{Giriş}

Ülkemizde yaşanan kaliteli kaba yem yetersizliği ruminant hayvanların beslenmesini ve performansını sınırlandırmaktadır (Alçiçek ve ark., 2010; Sayar ve ark., 2010; Temel ve Şahin, 2011). Bu durum özellikle otsu türlerin sarardığı, besin değerinin düştüğü ve bitkilerin dormant döneme girdiği yaz ve sonbahar aylarında daha da önem arz etmektedir. Oysa derin ve kuvvetli kök sistemlerine sahip çalı ve ağaçlar olağan dışı çevre koşullarında dahi yeşilliklerini ve üretim güçlerini devam ettirerek, yeter miktar ve kalitede yem materyali üretebilmektedirler (Papachristou ve Papanastasis, 1994; Temel ve Tan, 2011; Tan ve Temel, 2012). Sonuçta ise, bilim insanları çalı ve ağaç türlerinin çiftlik hayvanların beslenmesinde önemli bir yem kaynağı olduğunu ve ruminantların gereksinim duyduğu yem açı̆̆ını kapatmada önemli rol oynayabileceğini ortaya koymuşlardır (Tsiouvaras, 1987; Güven, 2004; Temel ve Tan, 2011; Dökülgen ve Temel, 2015; Oktay ve Temel, 2015).

Ruminant hayvanlar vejetasyonda yer alan türleri rastgele değil, seçici (genellikle lezzetli olan türleri veya bitki kısımlarını) otlama meyillindedirler. Bu durum çalı ve ağaç türleri için de geçerli olup, hayvanlar özellikle de keçi ve koyunlar bu formasyonların sadece yapraklarını değil, taze sürgün, sürgün+yaprak kısımlarını ve ayrıca bitkilerin ulaşılabilir kısımlarını daha çok tercih ettik görülmüştür (Temel, 2007; Temel ve Tan, 2011; Oktay ve Temel, 2015; Temel ve Kır, 2015). Yine bitkilerin fenolojik dönemlerine ve mevsimlere göre, türler üzerindeki otlanma baskısı farklııık gösterebilmektedir. Özellikle erken gelişme dönemine tekabül eden ilkbahar mevsiminde bitkiler hayvanlar tarafından daha fazla otlanma baskısına maruz kalmakta, oysa gelişme dönemlerinin ilerlemesiyle bu baskı azalmaktadır. Burada hayvanların otlanma tercihini azaltan bitkilerin sahip oldukları morfolojik özellikleri yanında besin içeriklerinin de büyük bir katkısının olduğu düşünülmektedir. Çünkü genç sürgün ve yapraklar gelişmesini tamamlamış bitki kısımlarına göre daha yumuşak ve körpe yapıda olup, hayvanlar tarafından daha fazla tercih edilmektedir (Dökülgen ve Temel, 2015; Oktay ve Temel, 2015). Yine taze bitki dokularında hücre bölünmesi ve genç hücre dokuları fazla olup, daha fazla yapısal olmayan karbonhidratlara ve daha az oranda yapısal karbonhidratlara sahiptiler (Lyons ve ark., 1999; Haddi ve ark., 2003; Kacar ve ark., 2006).

Bilindiği üzere çalı (maki) türleri Akdeniz iklim özelliğine sahip bölgelerde yaygın olarak yetişen formasyon tipleridir. Kilis îli de, Güneydoğu Anadolu step örtüsü ile, Akdeniz'in tipik bitki örtüsü olan maki arasında, geçit alanı durumundadır. Dolayısıyla bu coğrafyanın dağlık bölgelerinde, yaygın olarak bulunan çalılık (makilikler) alanlar, küçükbaş hayvanlar özellikle de, atletik vücut yapısına sahip keçiler için, iyi bir otlatma alanlarıdır. Ve bu alanlardan en yüksek hayvansal performansa ulaşabilmek ve en uygun otlatma dönemlerini ortaya koyabilmek için bu formasyonda yer alan türlerin farklı dönemlerde ürettikleri yem miktarları yanında besin içeriklerinin de ortaya konulması gerekmektedir. Bu amaçla, Kilis ekolojisinde yaygın olarak yetişen ve hayvanlar tarafından sıkça otlanan menengiç (Pistacia terebinthus L.) ve tesbih çalısı (Styrax officinalis L.)'nın mevsimsel ve otlanan bitki kısımlarına göre besin içeriğindeki değişimi belirlemek için bu çalışma planlanmıştır.

\section{Materyal ve Metot}

Çalışma yarı-kurak iklim özelliğine sahip Kilis coğrafyasında yer alan, 730 m rakımlı, Gotal Dağı, 
çalılık alanlarında yürütülmüştür. Uzun yıllar (1960 - 2012) ortalamasına göre, Kilis ilinin yıllık yağıs miktarı, ortalama $476.7 \mathrm{~mm}$, ortalama nem \%46.4 ve ortalama sıcaklık $17.1^{\circ} \mathrm{C}^{\prime}$ dir. Araştırmanın yapıldığı yılda ise, toplam yıllık yağış miktarı, ortalama sıcaklık ve nispi nem değerleri sırasıyla $227.5 \mathrm{~mm}, 18.0{ }^{\circ} \mathrm{C}$ ve $\% 45.9$ olarak ölçülmüştür. Bu sonuçlara göre denemenin yürütüldüğü yıl, uzun yıllar ortalamasına göre daha kurak bir yıl olmuştur (Çizelge 1).

Çizelge 1. Kilis il’inin uzun yıllar ve 2013 - 2014 yılına ait bazı iklim özellikleri*

Table 1. Some climate properties of Kilis province belong to 2013-2014 years and long-term averages*

\begin{tabular}{|c|c|c|c|c|c|c|}
\hline & \multicolumn{2}{|c|}{$\begin{array}{c}\text { Toplam yağış }(\mathrm{mm}) \\
\text { Total precipitation }(\mathrm{mm})\end{array}$} & \multicolumn{2}{|c|}{$\begin{array}{c}\text { Ortalama sıcaklık }\left({ }^{0} \mathrm{C}\right) \\
\text { Average temperature }\left({ }^{0} \mathrm{C}\right)\end{array}$} & \multicolumn{2}{|c|}{$\begin{array}{c}\text { Nispi nem (\%) } \\
\text { Relative humidity (\%) }\end{array}$} \\
\hline & 2013-2014 & UYO/LTA** & $2013-2014$ & UYO/LTA & $2013-2014$ & UYO/LTA \\
\hline Ekim/October & 8.4 & 32.5 & 18.8 & 19.7 & 29.0 & 42.0 \\
\hline Kasım/November & 16.3 & 59.7 & 14.7 & 12.4 & 56.4 & 47.0 \\
\hline Aralık/December & 41.2 & 81.7 & 6.1 & 7.3 & 55.3 & 67.5 \\
\hline Ocak/January & 36.6 & 76.3 & 8.3 & 5.8 & 71.0 & 67.6 \\
\hline Şubat/February & 9.5 & 70.8 & 9.8 & 7.0 & 35.9 & 61.2 \\
\hline Mart/March & 67.8 & 66.3 & 12.9 & 10.7 & 44.9 & 48.6 \\
\hline Nisan/April & 22.5 & 49.0 & 17.4 & 15.4 & 38.3 & 44.3 \\
\hline Mayıs/May & 3.1 & 23.9 & 21.6 & 20.7 & 40.1 & 42.0 \\
\hline Haziran/June & 0.1 & 7.0 & 25.7 & 25.3 & 35.7 & 31.8 \\
\hline Temmuz/July & - & 1.2 & 28.1 & 28.1 & 44.2 & 34.7 \\
\hline Ağustos/August & - & 3.3 & 28.9 & 27.9 & 45.7 & 32.4 \\
\hline Eylül/September & 22 & 5.0 & 23.9 & 24.9 & 53.7 & 37.7 \\
\hline $\begin{array}{l}\text { Toplam/Ortalama } \\
\text { Total/Average }\end{array}$ & 227.5 & 476.7 & 18.0 & 17.1 & 45.9 & 46.4 \\
\hline
\end{tabular}

* MGM (2014), **: Uzun Yıllar Ortalaması (1960-2012)/Long-term averages (1960-2012)

Mevcut araştırmada deneme alanın toprak özelliklerini ortaya koyabilmek için $0-60 \mathrm{~cm}$ derinliğinde toplam 16 noktadan toprak örnekleri alınmış ve yapılan analiz sonuçlarına göre; deneme alanı toprakları tınlı ve hafif alkali $(\mathrm{pH}$ : 7.8) bir yapıya sahip olup, kireç (\% 11.09) ve organik madde içeriği (\% 4.7) yüksek, tuzluluk (\% 0.016) ise bulunmamaktadır. Fosfor içeriği bakımından orta $\left(7.73 \mathrm{~kg} \mathrm{da}{ }^{-1}\right)$, potasyum yönünden $\left(55.0 \mathrm{~kg} \mathrm{da}^{-1}\right)$ ise yeterli görünmektedir.

Deneme 2014 yılında tesadüf bloklarında faktöriyel düzenlemeye göre, 4 tekrarlamalı olarak kurulmuştur. Araştırmada, yaprağını döken çok yıllık iki tür (Menengiç: Pistacia terebinthus L., ve tespih çalısı: Styrax officinalis L.), üç dönem (ilkbahar, yaz ve sonbahar) ve iki tane otlanan bitki kısmı (yaprak ve sürgün+yaprak) faktör olarak yer almıştır. Yaprak ve sürgün+yaprak örnekleri (3-4 cm uzunluğundaki uç sürgünler) otlanma görmemiş kısımlardan, hayvanların otlanma alışkanlıkları taklit edilerek, Nisan, Temmuz ve Eylül aylarının ortasında toplanmıştır. Toplanan örnekler, kâğıt torbalara konularak, önce açık havada ve sonra da $60{ }^{\circ} C^{\prime}$ ye ayarlı kurutma fırınında ağırlıkları sabit oluncaya kadar, kurutulmuş ve sonrasında ise, besin içeriği analizlerinin yapılması için öğütülmüştür.

Öğütülmüş örneklerde, Mikro Kjeldahl metoduna göre, toplam $\mathrm{N}$ tayini yapılmış ve daha sonra, \% azot oranları 6.25 katsayısı ile çarpılarak, Kacar, (1972)'ın belirttiği esaslara göre, ham protein (HP) oranları tespit edilmiştir. Yem örneklerinin nötr çözücülerde çözünmeyen lif (NDF), asit çözücülerde çözünmeyen lif (ADF) ve asit çözücülerde çözünmeyen lignin (ADL) oranları, Van Soest ve ark. (1991) tarafından geliştirilen metot kullanılarak belirlenmiştir. Bitkilerin ADF ve NDF analiz sonuçları kullanılarak, önce kuru madde sindirilebilirlikleri (KMS = 88.9 (0.779 x \%ADF) sonra, kuru madde tüketimi (KMT) $=120 /$ (\%NDF) ve daha sonra da, nispi yem değerleri (NYD= (KMS x KMT) / 1.29) belirlenmiştir (Morrison, 2003). Yem örneklerinin sindirilebilir enerji (SE) değerleri, Fonnesbeck ve ark. (1984) tarafından formüle edilen eşitlikle; SE $\left(\mathrm{Mcal} \mathrm{kg}^{-1}\right)=$ $0.27+0.0428 \times(\% \mathrm{KMS})$, Metabolik Enerji (ME) içerikleri ise, Khalil ve ark. (1986) tarafından geliştirilen formülle; $\mathrm{ME}\left(\mathrm{Mcal} \mathrm{kg}{ }^{-1}\right)=0.821 \times \mathrm{SE}$ (Mcal kg ${ }^{-1}$ ) hesaplanmıştır. 


\section{Verilerin analizi}

Elde edilen veriler JMP (5.0.1) istatistik paket programı kullanılarak, tesadüf bloklarında faktöriyel düzenlemeye göre varyans analizine tabii tutulmuş ve önemli çıkan ortalamalar $\mathrm{LSD}_{(0.05)}$ testine göre, gruplandırıması yapılmıştır.

\section{Araştırma Bulguları ve Tartışma}

Yapılan istatistik analizler sonucu üçlü interaksiyonlarının önemli çıktığı parametrelerde, ana faktörler ve ikili interaksiyonlar üzerinde ayrı ayrı durulmamış, üçlü interaksiyonlara göre, veri sunumu ve tartışması yapılmıştır. Sadece ikili interaksiyonlarının önemli çıktığı parametrelerde ise, yine ana faktörler üzerinde ayrı ayrı durulmamış, ikili interaksiyonlara göre veri sunumu ve tartışmasına gidilmiştir. İkili ve üçlü interaksiyonlarının önemsiz çıktığı parametrelerde ise, ana faktörler dikkate alınarak yorumlamaya gidilmiştir.

Ham protein oranı (\%) ve Asit çözücülerde çözünmeyen lif (\%)

Yapılan istatistiki analiz sonuçlarına göre, ham protein (HP) ve asit çözücülerde çözünmeyen lif (ADF) oranı üzerine, üçlü interaksiyon (tür $\mathrm{x}$ otlanan bitki kısmı x mevsim)'nun etkisi, \%5 ihtimal seviyesinde önemli bulunmuştur ( Şekil 1; Şekil 2). Buna göre, en yüksek HP (\%13.25) ve en düşük ADF içeriği (\%18.45) ilkbahar döneminde toplanan tespih çalısının yaprak örneklerinden ölçülmüştür.

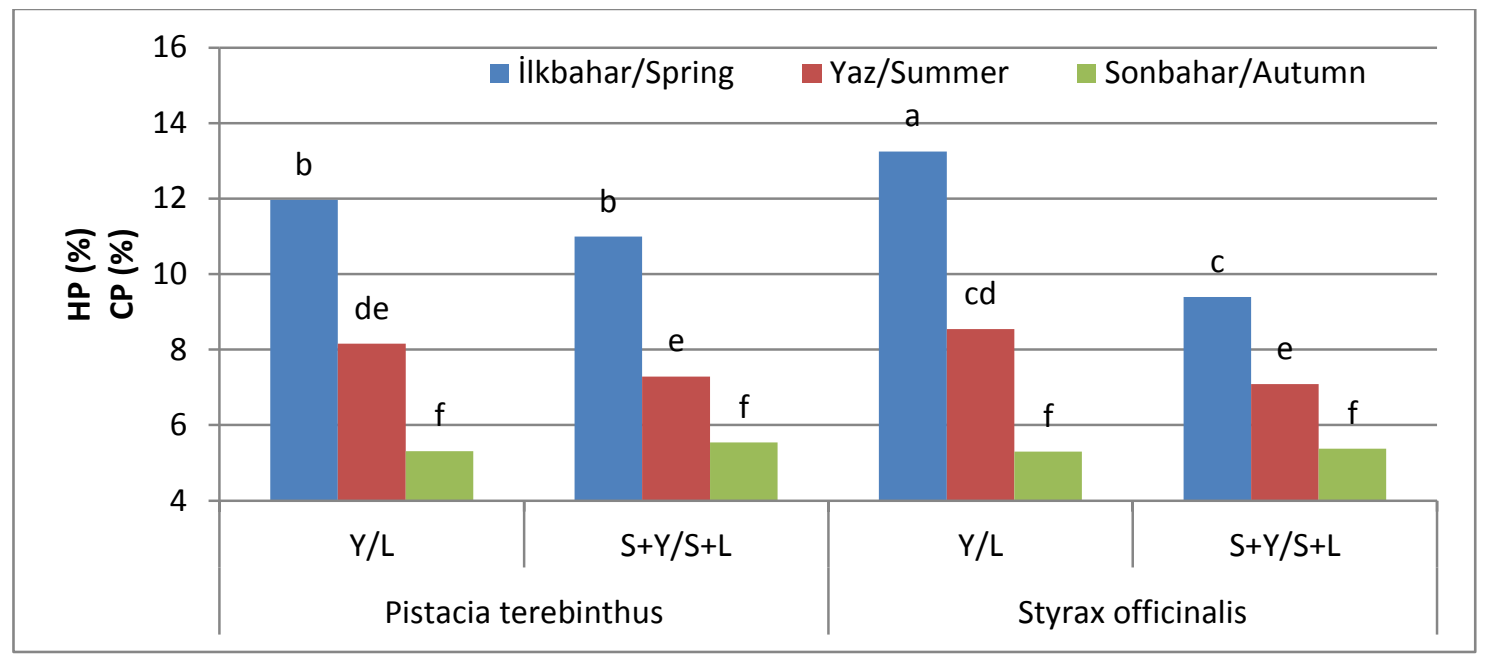

Şekil 1. Illkbahar, yaz ve sonbaharda menengiç ve tespih çalısının otlanan bitki kısımlarına ait ham protein (HP) içeriği. Aynı harfleri takip eden çizimler arasındaki fark $\mathrm{P}<0.05$ seviyesinde önemli değildir. Üçlü interaksiyona ait LSD değeri: 1.13*.Y: Yaprak, S+Y: Sürgün+Yaprak

Figure 1. The crude protein $(C P)$ content belonging to the grazed plant parts of terebinth and styrax tree in spring, summer and autumn. Difference between plots followed by the same letters are not significant at $P<0.05$. LSD value belonging to triple interaction: $1.13^{*}$. L: Leaf, $S+L$ : Shoot+Leaf

Oluşan bu farklılık, iki türün hem genetik yapı hem de, gelişme dönemlerine bağlı olarak, morfolojik yönden farklılık göstermesinden kaynaklanmış olabilir. İncelemeler sonucu, menengiç bitkisi erken gelişme döneminde tespih çalısına göre, daha sukulent yapıda bir yaprak ve sürgün gelişimi, geç gelişme döneminde (sonbahar) ise, daha sert yapıda bir yaprak ve daha sukkulent yapıda bir sürgün gelişimi gösterdiği görülmüştür. Bu da, tespih çalısının erken gelişme döneminde, menengiç bitkisine göre birim ağırlık başına daha fazla, kuru madde oranına sahip olmasına neden olmuştur. Nitekim, kuru madde, o yeme ait tüm besin maddelerini içeren kısımdır. Herhangi bir yemin kuru maddesi ne kadar çok ise, besin maddelerince zengin olma olasılığı da o oranda yüksek olacaktır (Kutlu ve ark., 2005). 
Dökülgen ve Temel, 2019. Harran Tarım ve Gıda Bilimleri Dergisi, 23(2): 178-188

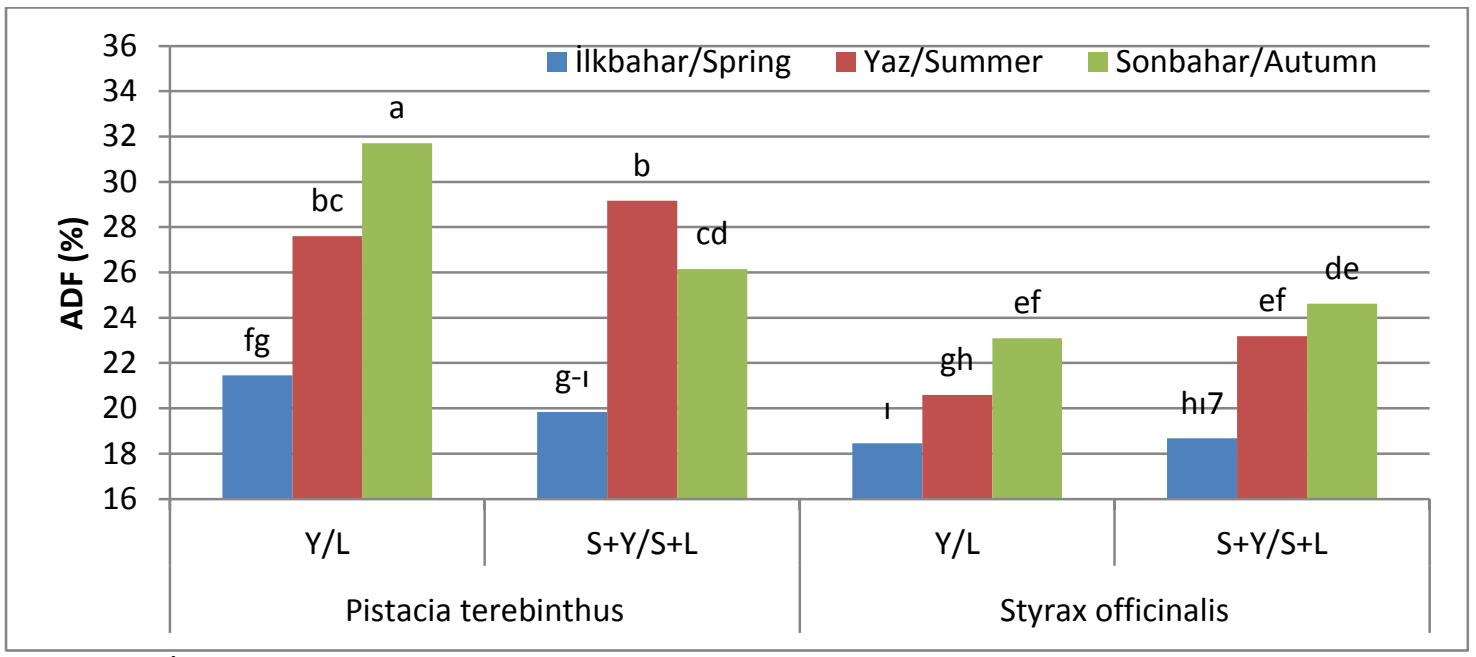

Şekil 2. İlkbahar, yaz ve sonbaharda menengiç ve tespih çalısının otlanan bitki kısımlarına ait asit çözücülerde çözünmeyen lif (ADF) içeriği. Aynı harfleri takip eden çizimler arasındaki fark $\mathrm{P}<0.01$ seviyesinde önemli değildir. Üçlü interaksiyona ait LSD değeri: $2.06^{* *}$. Y: Yaprak, $\mathrm{S}+\mathrm{Y}$ : Sürgün+Yaprak

Figure 2. The Acid detergent fibre (ADF) content belonging to the grazed plant parts of terebinth and styrax tree in spring, summer and autumn. Difference between plots followed by the same letters are not significant at $P<0.01$. LSD value belonging to triple interaction: $2.06^{* *}$. L: Leaf, $S+L:$ Shoot+Leaf

Diğer taraftan, hücre içi maddelerini (ham protein oranına, nişasta, şeker, yağ) oluşturan yapısal olmayan karbonhidratlar, genç hücre dokularının yoğun olarak bulunduğu erken gelişme dönemlerinde, hücre duvarı maddeleri olan yapısal karbonhidratlar (hemiselüloz, selüloz, lignin, kütin ve silikatlar) da, yaşı hücre dokularının bulunduğu bitkilerin geç gelişme dönemlerinde, daha fazla bulunmaktadır (Akyıldız, 1986; Lyons ve ark., 1999; Kacar ve ark., 2006; Mountousis ve ark., 2008). Farklı ekolojik koşullarda yürütülen pek çok çalışmada da, çalı ve ağaç türlerinin erken gelişme dönemlerinde HP içeriğinin yüksek, ADF içeriğinin düşük, olgunlaşmayla birlikte ise, bu değerlerin tersi bir durum seyrettiği rapor edilmiştir (Papachristou ve Papanastasis, 1994; Tolunay ve ark., 2009; Ataşoğlu ve ark., 2010; Parlak ve ark., 2011a; Canbolat, 2012; Tan ve Temel, 2012; Oktay ve Temel, 2015). Mevcut bu sebeplerden dolayı, tespih çalısının ilkbahar döneminde toplanan yaprak örneklerinin daha fazla ham protein ve daha düşük bir ADF içeriğine sahip olduğu düşünülmektedir.

Çizelge 2. Otlanan bitki kısımları ve mevsimlere göre menengiç ve tespih çalısının NDF içeriği (\%)

Table 2. The NDF content of terebinth and styrax tree according to the grazed plant parts and seasons (\%)

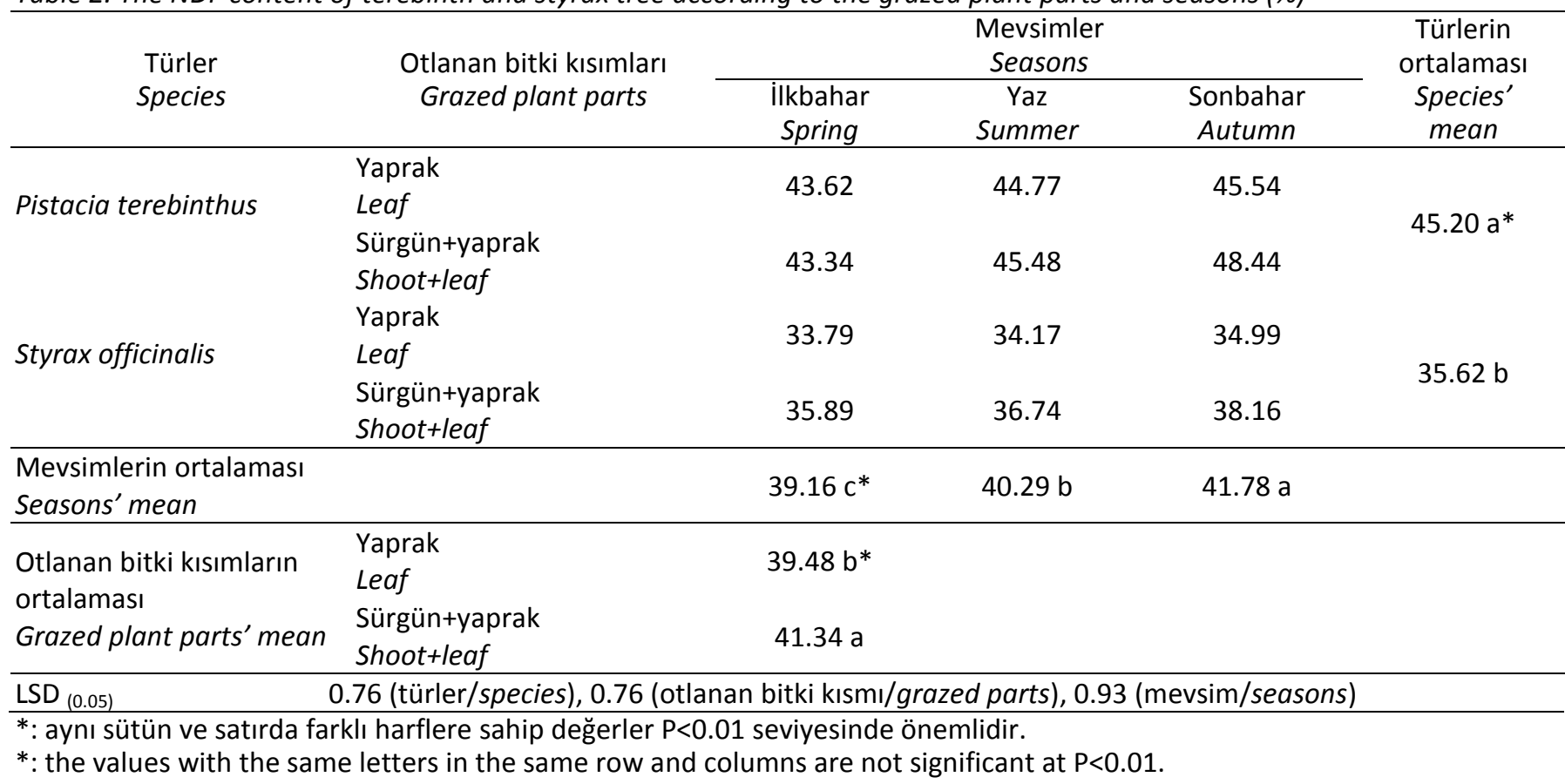


Nötr çözücülerde çözünmeyen lif (\%)

Menengiç ve tespih çalısının nötr çözücülerde çözünmeyen lif (NDF) oranına ait varyans analiz sonuçları ve ortalama değerler Çizelge 2'de verilmiştir. Çizelge 2 incelendiğinde türler, otlanan bitki kısımları ve mevsimlere göre NDF içeriği $\mathrm{P}<0.01$ ihtimal sınırlarında çok önemli bulunmuştur.

Bu çalışmada, sürgün+yaprak örneklerinin, yaprak örneklerine göre daha yüksek bir NDF içeriğine sahip olduğu görülmüştür (Çizelge 2). Bu, sürgün+yaprak örneklerinde, ince sürgünden kaynaklanan ilave bir lif artışının meydana gelmesi ve hücre protoplazma bileşiklerinin azalmasından, kaynaklanmış olabilir. Benzer olarak yürütülen çalışmalarda da, çalı ve ağaç yapraklarının, sap veya ince sürgünlere göre daha az lifli bileşik, daha fazla genç hücre ve hücre içi bileşenlerine sahip olduğunu ortaya konulmuştur (Lyons ve ark., 1999; Kacar ve ark., 2006; Mountousis ve ark., 2008).

Yine ilkbahar dönemi diğer iki döneme göre daha düşük bir NDF içeriğine sahip olmuş ve olgunlaşma döneminin ilerlemesiyle NDF oranlarında artışlar meydana gelmiştir (Çizelge 2). Menengiç ve tespih çalısı yaprağını döken çok yıllık türler olup, havaların ısınmaya başladığı ilkbahar döneminde genç yaprak ve sürgünler oluşturmakta, ileri gelişme dönemlerinde ise yaprak ve sürgünleri sertleşmekte ve havaların soğumaya başladığı sonbahar aylarından itibaren ise kartlaşmış yapraklarını dökme eğilimindedirler. $\mathrm{Bu}$ sebeplerden dolayı türler erken gelişme dönemlerine tekabül eden ilkbahar mevsiminde bünyesinde daha az lifli bileşikler (NDF) bulundurmaktadırlar. Nitekim, Parissi ve ark. (2005), hücre duvarı gelişmesinin bitkinin gelişmesi ile alakalı olduğunu ve bitkiler olgunlaştıkça, NDF gibi hücre duvarı bileşiklerinin arttığını belirtmişlerdir. Konu ile ilgili olarak, Parlak ve ark. (2011a), yürüttükleri bir çalışmada, çalı ve ağaç türlerinin erken gelişme dönemlerinde (ilkbahar mevsiminde), NDF içeriklerinin düşük, sonbahar dönemlerinde ise yüksek olduğunu rapor etmişlerdir.

\section{Asit çözücülerde çözünmeyen lignin (\%)}

Asit çözücülerde çözünmeyen lignin (ADL) oranı açısından ikili interaksiyon (mevsim $\mathrm{x}$ otlanan bitki kısmı) çok önemli bulunmuş $(P<0.01)$ ve ortalama değerler Şekil 3'de sunulmuştur. Şekil 3'e bakıldığında, ilkbahar mevsiminde alınan yaprak ve sürgün+yaprak örneklerinin ADL oranları istatistiki olarak, aynı grupta yer almış ve en düşük değerlere sahip olmuştur. En yüksek ADL oranı (\%9.18) ise yaz döneminde toplanan sürgün+yaprak örneklerinden elde edilmiştir.

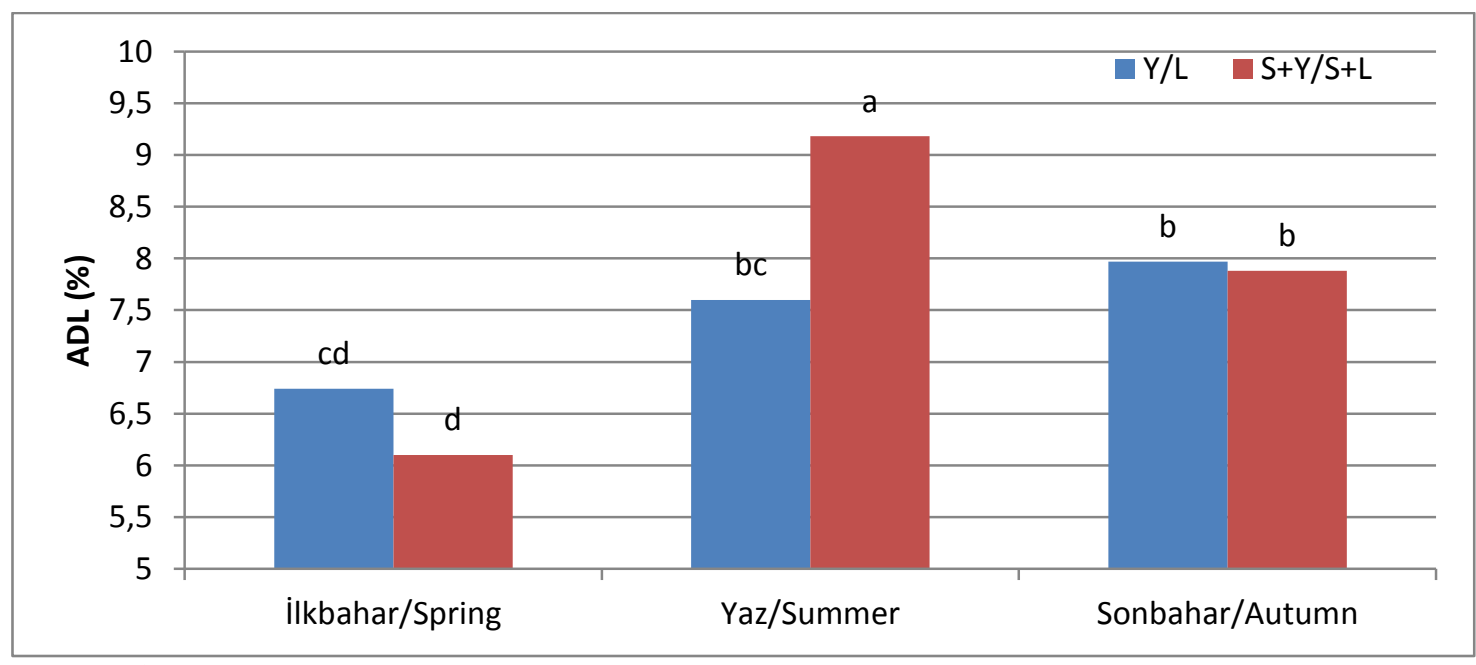

Şekil 3. Illkbahar, yaz ve sonbaharda otlanan bitki kısımlarının asit çözücülerde çözünmeyen lignin (ADL) oranı. Aynı harfleri takip eden çizimler arasındaki fark $\mathrm{P}<0.01$ seviyesinde önemli değildir. İkili interaksiyona ait LSD değeri: 0.80**. Y: Yaprak, S+Y: Sürgün+Yaprak

Figure 3. The acid detergent lignin( $A D L)$ ratio of the grazed plant parts in spring, summer and autumn. Difference between plots followed by the same letters are not significant at $P<0.01$. LSD value belonging to binary interaction: $0.80^{* *}$. L: Leaf, $S+L$ : Shoot+Leaf 
$\mathrm{Bu}$, olgunlaşma ile saplardaki ligninleşmenin yapraklara göre, daha yüksek olmasından kaynaklanmış olabilir. Benzer sonuçlar, çalı ve ağaç türlerinde (Kökten ve ark., 2012) yapılan çalışmalarla ortaya konmuş ve bizim sonuçlarımızı desteklemektedir. Nitekim, bitkilerin sindirilmeyen kısmı olan ve lignin miktarını ifade eden $A D L$, yem dokusunda, hücre duvarı maddelerini içermektedir. Hücre duvarı gelişimi ise, bitkilerin gelişmesi ile alakalı olup, bitkiler olgunlaştıkça, lifli bileşiklerin oranı artmakta (Açıkgöz, 2001; Frost ve ark.,2008) ve sonuçta ise, $A D L$ gibi hücre duvarı bileşenlerinde artışlar olmaktadır (Parissi ve ark., 2005; Parlak ve ark., 2011a, 2011b; Oktay ve Temel, 2015). Ayrıca, bitki gövdesinin sertliği ligninden kaynaklanmaktadır. $\mathrm{Bu}$ nedenle, yaprak ve çiçeklere göre saptaki lignin oranı çok daha fazla olabilmektedir (Açıkgöz, 2001). Farklı ekolojilerde yürütülen çalışmalarda da, çalı ve ağaç türlerinin olgunlaşmasıyla, ADL içeriklerinin arttığı ifade edilmiştir (Parlak ve ark.,2011a, 2011b; Oktay ve Temel, 2015).

Kuru madde sindirilebilirliği (\%), Sindirilebilir enerji (Mcal kg-1) ve Metabolik enerji ( $\mathrm{Mcal} \mathrm{kg}^{-1}$ )

Yemlerin ortalama kuru madde sindirilebilirliği (KMS) Şekil 4'de, sindirilebilir enerji (SE) içeriği Şekil 5'de ve metabolik enerji (ME) değerleri ise Şekil 6'da sunulmuştur. Analiz sonuçlarına göre, KMS, SE ve ME açısından üçlü interaksiyonlar sırasıyla \%5, \%1 ve \%5 ihtimal seviyesinde önemli bulunmuştur. Bu sonuçlara göre, en yüksek kuru madde sindirilebilirliği (\%74.53), sindirilebilir enerji (3.42 $\mathrm{Mcal} \mathrm{kg}^{-1}$ ) ve metabolik enerji (2.84 Mcal kg-1) içerikleri, ilkbahar döneminde toplanan tespih çalısına ait yaprak örneklerinden alınmıştır.

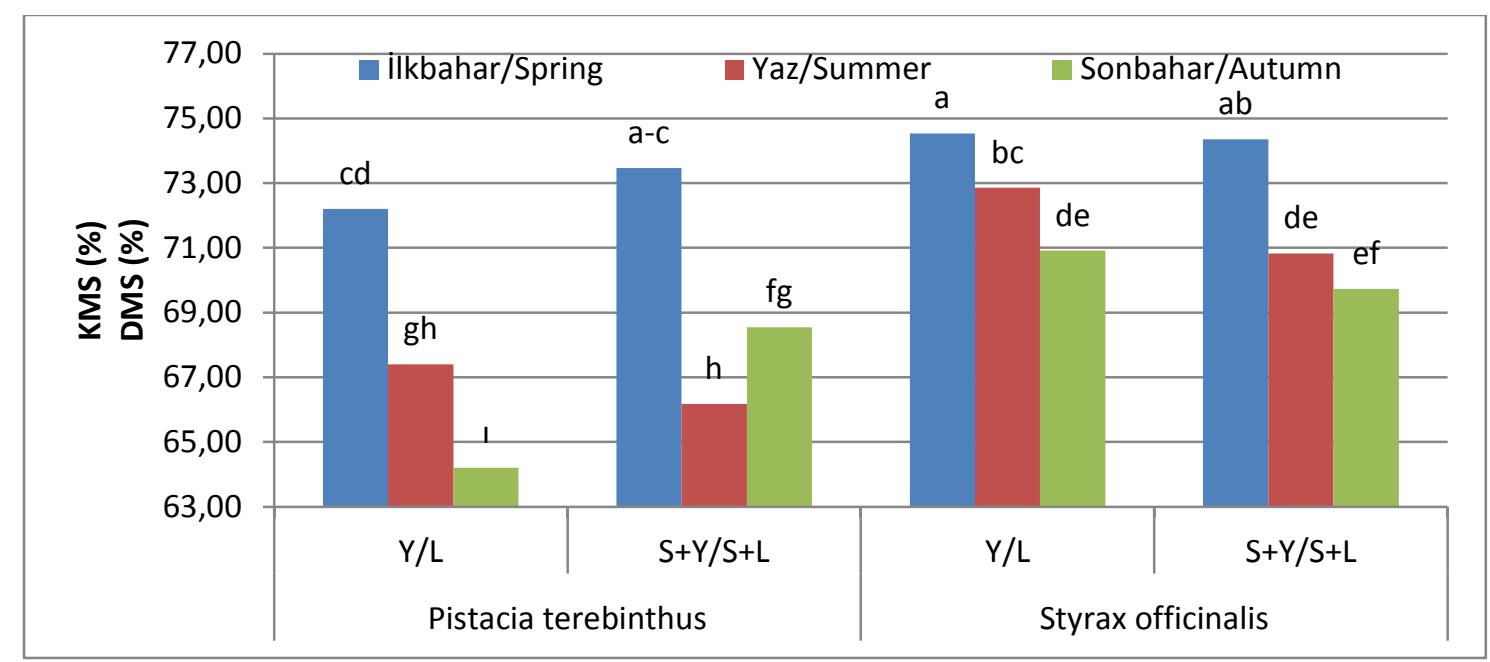

Şekil 4. Illkbahar, yaz ve sonbaharda menengiç ve tespih çalısının otlanan bitki kısımlarına ait kuru madde sindirilebilirliği (KMS). Aynı harfleri takip eden çizimler arasındaki fark $\mathrm{P}<0.05$ seviyesinde önemli değildir. Üçlü interaksiyona ait LSD değeri: 1.13*. Y: Yaprak, S+Y: Sürgün+Yaprak

Figure 4. The dry matter digestibility (DMD)belonging to the grazed plant parts of terebinth and styrax tree in spring, summer and autumn. Difference between plots followed by the same letters are not significant at $P<0.05$. LSD value belonging to triple interaction: $1.13^{*}$. L: Leaf, $S+L$ : Shoot+Leaf

Ayrıca, ilkbahar döneminde toplanan tespih çalısının yaprak ve sürgün+yaprak örnekleri ile, yine ilkbaharda toplanan menengiç bitkisinin sürgün+yaprak örneklerinin kuru madde sindirilebilirliği, sindirilebilir enerji ve metabolik enerji değerleri, aynı grupta yer almış ve istatistiki olarak aralarında önemli bir farklılık görülmemiştir. 
Dökülgen ve Temel, 2019. Harran Tarım ve Gıda Bilimleri Dergisi, 23(2): 178-188

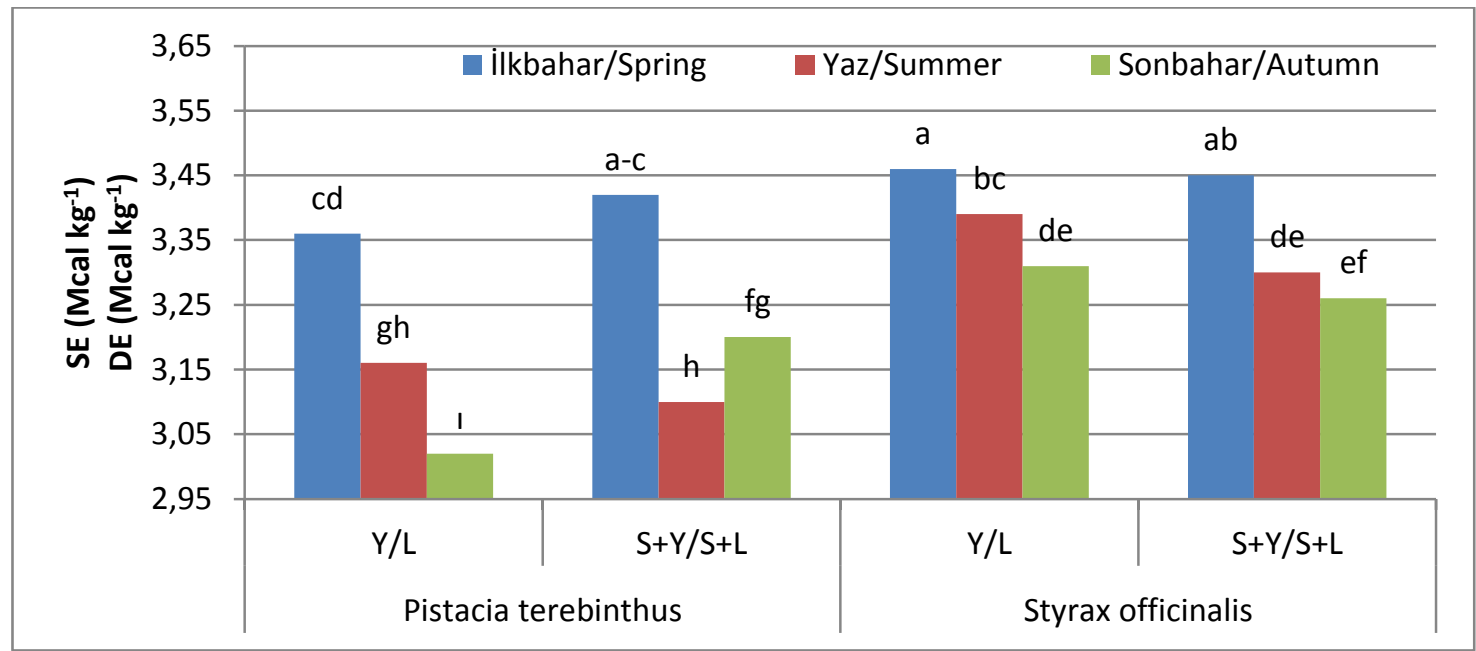

Şekil 5. İlkbahar, yaz ve sonbaharda menengiç ve tespih çalısının otlanan bitki kısımlarına ait sindirilebilir enerji (SE) içeriği. Aynı harfleri takip eden çizimler arasındaki fark $\mathrm{P}<0.01$ seviyesinde önemli değildir. Üçlü interaksiyona ait LSD değeri: 1.13**. Y: Yaprak, S+Y: Sürgün+Yaprak

Figure 5. The digestible energy (DE) content belonging to the grazed plant parts of terebinth and styrax tree in spring, summer and autumn. Difference between plots followed by the same letters are not significant at $P<0.01$. $L S D$ value belonging to triple interaction: $1.13^{* *}$. L: Leaf, $S+L$ : Shoot+Leaf

Diğer taraftan, en düşük kuru madde içerikleri, sonbahar döneminde toplanan sindirilebilirliği (\%64.20), sindirilebilir enerji (3.02 menengiç bitkisinin yaprak örneklerinde Mcal $\mathrm{kg}^{-1}$ ) ve metabolik enerji (2.48 Mcal kg${ }^{-1}$ ) ölçülmüştür.

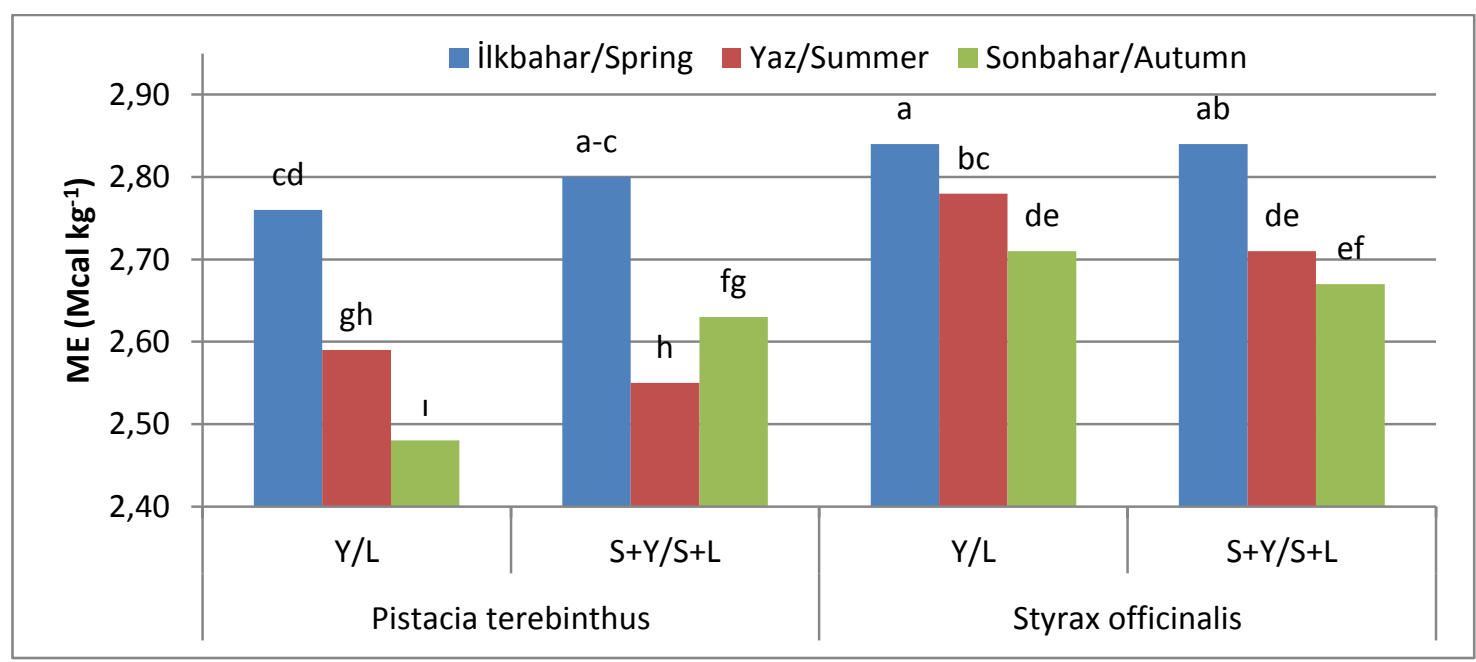

Şekil 6. Illkbahar, yaz ve sonbaharda menengiç ve tespih çalısının otlanan bitki kısımlarına ait metabolik enerji (ME) içeriği. Aynı harfleri takip eden çizimler arasındaki fark $\mathrm{P}<0.05$ seviyesinde önemli değildir. Üçlü interaksiyona ait LSD değeri: 1.13*. Y: Yaprak, S+Y: Sürgün+Yaprak

Figure 6. The metabolic energy (ME) content belonging to the grazed plant parts of terebinth and styrax tree in spring, summer and autumn. Difference between plots followed by the same letters are not significant at $P<0.05$. $L S D$ value belonging to triple interaction: $1.13^{*}$. L: Leaf, $S+L$ : Shoot+Leaf

Oluşan bu farklılıklar, türlerin genetik yapısına bağlı olarak değişmekle birlikte, gelişme dönemleri ve bitki kısımlarına göre, farklı oranda lifli bileşikler içermesinden kaynaklanmış olabilir. Çünkü, bitki yaprakları ince sürgün ve saplara göre daha düşük oranda lifli bileşiklere sahiptirler (Buxton, 1996; Claessens ve ark.,2005). Dolayısıyla, düşük NDF ve ADF içeriğine sahip yaprak örnekleri, daha yüksek oranda sindirilebilmekte ve daha yüksek metabolik enerji içeriğine sahip olabilmektedir. Ayrıca, bitkiler gelişme ve olgunlaşmalarını genellikle sonbahar aylarında tamamladıklarından, ileri gelişme dönemlerine göre, büyüme dönemi başlangıcında daha düşük oranda kuru madde ve daha yüksek oranda yapısal olmayan hücre içi bileşenlere sahip 
olabilmektedirler (Claessens ve ark., 2005). Başka bir ifade ile, lifli bileşikler genellikle, hücre duvarlarında ve hücre duvarı bileşenleri ise, genç dokulardan ziyade yaşlı kısımlarda, daha bol bulunmaktadır (Lyons ve ark.,1999). Dolayısıyla, bitkilerin ileri gelişme dönemlerinde, yapraklar ve genç sürgünler ligninleşmekte, hücre protoplazma bileşikleri azalmakta ve sonuçta ise, düşük sindirilebilirlik ve metabolik enerji içeriği ortaya çıkmaktadır (Haddi ve ark., 2003; Parissi ve ark., 2005; Mountousis ve ark., 2008). Bu nedenlerden dolayı, büyüme dönemi başlangıcı olan ilkbahar mevsiminde, yapraklar daha yüksek sindirilebilir ve metabolik enerji miktarına, olgunlaşma döneminin ilerlemesi ile de, daha düşük değerlere sahip olmuş olabilir. Benzer sonuçlar, farklı araştırmacılar tarafından da ortaya konulmuş ve KMS, SE ve ME içeriklerinin, bitkilerin yapraklarında ve erken gelişme dönemlerinde, daha yüksek olduğu ifade edilmiştir (Pecetti ve ark., 2007; Asaadi ve Yazdi, 2011; Kökten ve ark., 2012; Dökülgen ve Temel, 2015; Oktay ve Temel, 2015).

\section{Nispi yem değeri}

Nispi yem değeri (NYD) açısından, türxotlanan bitki kısmı interaksiyonu, $\mathrm{P}<0.05$ ihtimal seviyesinde, önemli bulunmuş ve ortalama değerler, Şekil 7'de yer almıştır. Şekil 7'ye bakıldığında, menengiç bitkisinin yaprak ve sürgün+yaprak örneklerinin nispi yem değerleri, istatistiki olarak aynı grupta yer almış ve en düşük değerlere sahip olmuştur. En yüksek NYD (197.50) ise, tespih çalısından alınan yaprak örneklerinden ölçülmüştür.

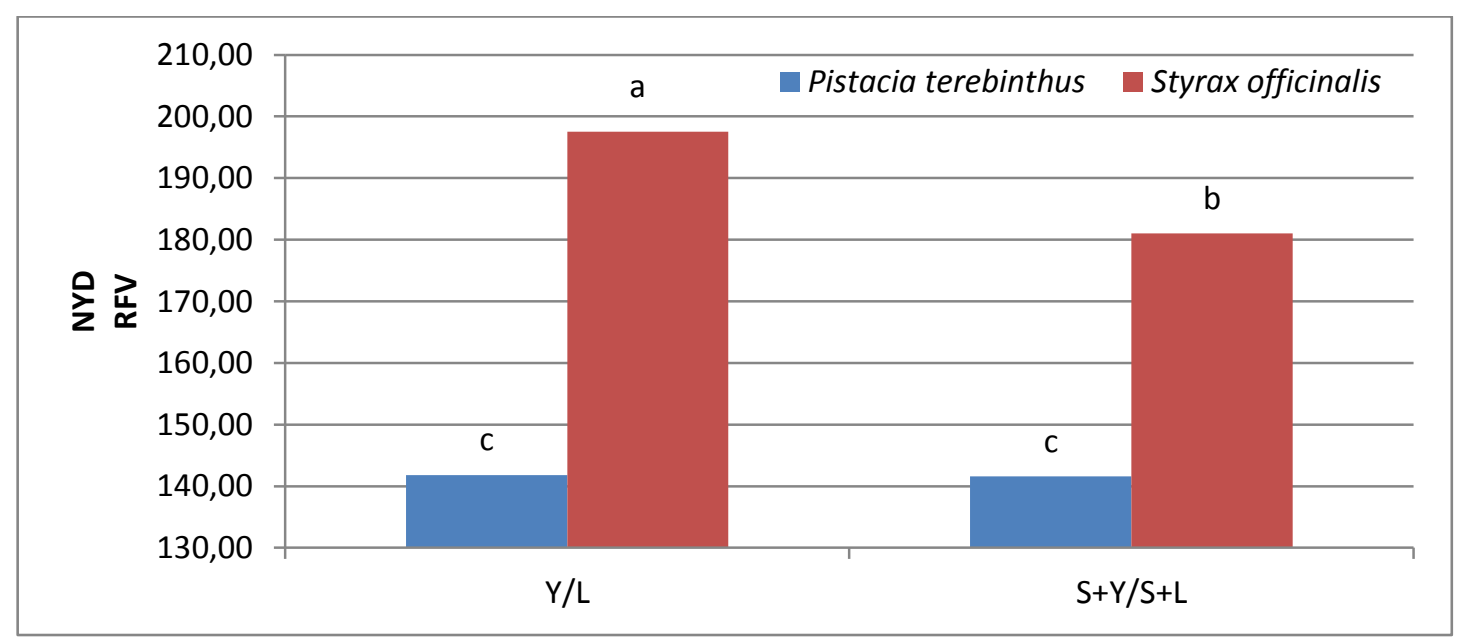

Şekil 7. Menengiç ve tespih çalısının otlanan bitki kısımlarına ait nispi yem değeri (NYD). Aynı harfleri takip eden çizimler arasındaki fark $P<0.01$ seviyesinde önemli değildir. İili interaksiyona ait LSD değeri: $0.65^{* *}$.Y: Yaprak, S+Y: Sürgün+Yaprak

Figure 7. The relative feed value (RFV) belonging to the grazed plant parts of terebinth and styrax tree. Difference between plots followed by the same letters are not significant at $P<0.01$. LSD value belonging to binary interaction: $0.65^{* *}$. L: Leaf, $S+L$ : Shoot+Leaf

$\mathrm{Bu}$, genetik ve morfolojik yapı yönünden benzerlik göstermeyen bu iki türün, örneklemesi yapılan kısımlarına göre, kimyasal kompozisyon içeriklerinin farklılık göstermesinden kaynaklanmış olabilir. Genel olarak, daha fazla yapısal olmayan karbonhidratlara sahip yapraklar, daha fazla lifli bileşiklere sahip sürgün+yaprak kısımlarına göre, daha düşük oranda NDF ve ADF içeriğine sahip olmaktadırlar (Kacar ve ark., 2006). Dolayısıyla, bitki kısımlarında bulunan lif oranı, yemin NYD'ni büyük oranda etkilemektedir. Çizelge 2 ve Şekil 2'ye bakıldığında da, tespih çalısı yapraklarının daha düşük oranda hücre çeperi bileşenlerine (NDF ve ADF oranı) sahip olduğu ve bundan dolayı, NYD'nin yüksek olduğu düşünülmektedir. Çünkü nispi yem değeri, NDF ve ADF değerlerinden yararlanılarak hesaplanan (Moore ve Underander, 2002), yemin besleme değerini ve kalitesini rakamsal olarak gösteren bir ölçüdür (Ball ve ark., 1996). Bu sonuçlar, Abdulrazak ve ark. (2000) ve Kamalak (2006) tarafından elde edilen bulgularla uyum içerisinde olup, bizim buğularımızı destekler niteliktedir. 


\section{Sonuçlar}

Sonuç olarak, incelemeye alınan 2 maki türü, her ne kadar gelişme dönemleri ve otlanan bitki kısımlarına göre, besin içerikleri farklııı gösterse de, incelenen kalite parametreleri açısından, ilkbahar ve yaz dönemlerinde otlatılmasının uygun olduğu ve ruminantların beslenmesinde, iyi bir alternatif besin kaynağı olabileceği ortaya konulmuştur. Ayrıca, çalı yaprakları, sürgün+yaprak kısımlarına göre daha yüksek kalitede bir yem materyali üretmiştir.

\section{Ekler}

"Bu çalışma Iğdır Üniversitesi Bilimsel Araştırma Projeleri Koordinasyon Birimince Desteklenmiştir. Proje Numarası: 2014-FBE-L11" Makale, Hasan DÖKÜLGEN'nin Yüksek Lisans Tezinin bir bölümünü içermektedir.

Bu makale abstract olarak; 25-27 Nisan 2018, Şanlıurfa da yapılan 1. Uluslararası GAP Tarım ve Hayvancilık Kongresi'nde sunulmuştur.

\section{Kaynaklar}

Abdulrazak, S.A., Fujihara, T., Ondiek, J.K. \& Ørskov, E.R. (2000). Nutritive Evaluation of Some Acacia Tree Leaves from Kenya. Animal Feed Science Technology, 85 (1-2), 89-98.

Açıkgöz, E. (2001). Yem Bitkileri (3. Baskı). Uludağ Üniversitesi Güçlendirme Vakfı Yayın No: 182. VIPAŞ A.Ş. Yayın No: 58, Bursa, 584s.

Akyıldız, A.R. (1986).Yemler Bilgisi ve Teknolojisi. Ankara Üniversitesi Ziraat Fakültesi Yayınları, Yayın No:974, Ders Kitabı No:286, Ankara.

Alçiçek, A., Kılıç, A., Ayhan, V. \& Özdogan, M. (2010).Türkiye'de Kaba Yem Üretimi ve Sorunları. Türkiye Ziraat Mühendisliği VII. Teknik Kongresi, 1115 Ocak, Ankara.

Asaadi, A.M. \& Yazdi, A.K., 2011. Phenological Stage Effets on Forage Quality of Four Forbs Species. Journal of Food Agriculture and Environment, 9(2): 380-384.

Ataşoğlu, C., Şahin, S., Canbolat, Ö. \& Baytekin, H. (2010). The Effect of Harvest Stage on The Potential Nutritive Value of Kermes Oak (Quercus coccifera) Leaves. Livestock Research for Rural Development, 22(2): 182-185.

Ball, D.M., Hoveland, C.S. \& Lacefield, D.D. (1996). Forage Quality. In: Southern Forages ( $2^{\text {nd }}$ edition). p. 124 132. Potash and Phosphate Institute and Foundation for Agronomic Research, Norcross, GA.

Buxton, D.R. (1996). Quality - Related Characteristics of Forages as Influenced by Plant Environment and
Agronomic Factors. Animal Feed Science Technology, 59(1-3): 37-49.

Canbolat, Ö. (2012). Determination of Potential Nutritie Value of Exotic Tree Leaves in Turkey. Kafkas Üniversitesi Veterinerlik Fakültesi Dergisi, 18(3): 419423.

Claessens, A., Michaund, R., Belanger, G. \& Mather, D.E. (2005). Leaf and Stem Characteristics of Timothy Plants Divergently Selected for The Ratio of Lignin to Cellulose. Crop Science, 45(6): 2425-2429.

Dökülgen, H. \& Temel, S. (2015). Yaprağını Döken Karaçalı (Palirus spina-christi Mill.) Türünde Yaprak ve Yaprak+Sürgünlerinin Mevsimsel Besin İçeriği Değişimi. Iğdır Üniversitesi Fen Bilimleri Enstitüsü Dergisi, 5(3): 57-65.

Fonnesbeck, P.V., Clark, D.H., Garret, W.N. \& Speth, C.F. (1984). Predicting Energy Utilization from Alfalfa Hay from The Western Region. Proceedings of American Animal Science, 35: 305-308.

Frost, R.A., Wilson, L.M., Launchbaugh, K.L. \& Hovde, E.M. (2008). Seasonal Change in Forage Value of Rangeland Weeds in Northern Idaho. Invasive Plant Science and Management, 1(4): 343-351.

Güven, M. (2004). Kargapazarı Dağı Florasında Bulunan Çalı Türlerinin Tespiti ve Çoğaltma Teknikleri ile Yem Değerlerinin Belirlenmesi (Doktora Tezi), Atatürk Üniversitesi Fen Bilimleri Enstitüsü Tarla Bitkileri Anabilim Dalı, Erzurum, $90 \mathrm{~s}$.

Haddi, M.L., Filacorda, S., Meniai, K., Rollin, F. \& Susmel, P. (2003). In Vitro Fermentation Kinetics of Some Halophyte Shrubs Sampled at Three Stages of Maturity. Animal Feed Science Technology, 104: 215225.

Kacar, B. (1972). Bitki ve Toprağın Kimyasal Analizleri: II. Bitki Analizleri. Ankara Üniversitesi Ziraat Fakültesi Yayınları, No: 453, Ankara, 464s.

Kacar, B., Katkat, A.V. \& Öztürk, Ş. (2006). Bitki Fizyolojisi (2. Baskı). Nobel Yayın Dağıtım, Ankara, 563s.

Kamalak, A. (2006). Determination of Nutritive Value of a Native Grown Shrub, Glycyrrhiza glabra L. Using in Vitro and in Situ Measurements. Small Ruminant Research, 64(3): 268-278.

Khalil, J.K., Sawaya, W.N. \& Hyder, S.Z. (1986). Nutrient Composition of Atriplex Leaves Grown in Saudi Arabia. Journal of Range Management, 39: 104-107.

Kökten, K., Kaplan, M., Hatipoğlu, R., Saruhan, V. \& Çınar, S. (2012). Nutritive Values of The Leaves of Mediterranean Shrubs. Journal of Animal and Plant Sciences, 22(1): 188-194.

Kutlu, H.R., Görgülü, M. \& Çelik, L.B. (2005). Genel Hayvan Besleme (Ders Notu). Çukurova Üniversitesi Ziraat Fakültesi Zootekni Bölümü, Yemler ve Hayvan Besleme Anabilim Dalı, Adana, 175s.

Lyons, R.K., Machen, R.V. \& Forbes, T.D.A. (1999). Why Range Forage Quality Changes. Texas Agriculture Extension Service, B- 6036, 7p.

MGM. (2014). Başbakanlık DMi Genel Müdürlüğü Meteroloji Bültenleri, Ankara.

Moore, J.E. \& Undersander, D.J. (2002). Relative Forage Quality: A proposal for replacement for Relative Feed Value. 2002 Proceedings National Forage Testing Association.

Morrison, J.A. (2003). Hay and Pasture Management. 
Chapter 6. Illinois Agronomy Handbook, 72p.

Mountousis, J., Papanikolaou, K., Stanogias, G., Chatzitheodoridis, F. \& Roukos, C. (2008). Seasonal Variation of Chemical Composition and Dry Matter Digestibility of Rangelands in NW Greece. Journal of Central European Agriculture, 9(3): 547-556.

Oktay, G. \& Temel, S. (2015). Ebu Cehil (Calligonum polygonoides L. ssp. commosum (L'Her.) Çalısının Yıllık Yem Değerinin Belirlenmesi. Gaziosmanpaşa Üniversitesi Ziraat Fakültesi Dergisi, 32(1): 30-36.

Papachristou, T.G. \& Papanastasis, V.P. (1994). Forage Value of Mediterranean Deciduous Woody Fodder Species and its Implication to Management of Silvo-Pastoral Systems for Goats. Agroforestry Systems, 27: 269282.

Parissi, Z.M., Papachristou, T.G. \& Nastis, A.S. (2005). Effect of Drying Method on Estimated Nutritive Value of Browse Species Using an in Vitro Gas Production Technique. Animal Feed Science and Technology, 123-124(1): 119-128.

Parlak, A.O., Gökkuş, A., Hakyemez, B.H. \& Baytekin, H. (2011a). Forage Quality of Deciduous Woody and Herbaceous Species Throughout a Year in Mediterranean Shrublands of Western Turkey. Journal of Animal and Plant Sciences, 21(3): 513518.

Parlak, A.O., Gökkuş, A., Hakyemez, B.H. \& Baytekin, H. (2011b). Forage Yield and Quality of Kermes Oak and Herbaceous Species Throughout a Year in Mediterranean Zone of Western Turkey. Journal of Food, Agriculture and Environment, 9(1): 510-515.

Pecetti, L., Tava, A., Pagnotta, M.A. \& Russi, L. (2007). Variations in Forage Quality and Chemical Composition Among Italian Accessions of Bituminaria bituminosa (L.) Strit. Journal of Science and Food Agriculture, 87: 985-991.

Sayar, M., Anlarsal, M. and Başbağ, M. (2010). Güneydoğu
Anadolu Bölgesinde Yem Bitkileri Tarımının Mevcut Durumu Sorunları ve Çözüm Önerileri. Harran Tarım ve Gıda Bilimleri Dergisi, 14(2): 59-67.

Tan, M. \& Temel, S. (2012). Alternatif Yem Bitkileri. Atatürk Üniversitesi Ziraat Fakültesi Ders Yayınları No: 246, Erzurum, 195-207ss.

Temel, S. (2007). Erdemli (Mersin) Yöresi Makiliklerinde Çalı Türlerinin Tespiti ve Yem Değerlerinin Belirlenmesi Üzerine Bir Araştırma (Doktora Tezi), Atatürk Üniversitesi Fen Bilimleri Enstitüsü, Erzurum, $154 \mathrm{~s}$.

Temel, S. \& Şahin, K. (2011). Iğdır ilinde Yem Bitkilerinin Mevcut Durumu, Sorunları ve Çözüm Önerileri. Yüzüncü Yıl üniversitesi Tarım Bilimleri Dergisi, 21(1): 64-72.

Temel, S. \& Tan, M. (2011). Fodder Values of Shrub Species in Maquis in Different Altitudes and Slope Aspects. The Journal of Animal and Plant Sciences, 21(3): 508512.

Temel, S. \& Kır, A.E. (2015). Bazı Çalı ve Ağaç Türlerinin Mevsimsel Dönem ve Hayvan Gruplarına Göre Otlanmada Tercih Durumlarının Belirlenmesi. International Journal of Agriculture and Wildlife Science, 1(1): 31-39.

Tolunay, A., Adıyaman, E., Akyol, A. \& Ince, D. (2009). Herbage Growth and Fodder Yield Characteristics of Kermes Oak (Quecus coccifera L.) in a Vegetation Period. Journal of Animal and Veterinary Advances, 8(2): 290-294.

Tsiouvaras, C.N. (1987). Ecology and Management of Kermes Oak (Quercuscoccifera L.) Pastures in Greece. A Review. Journal of Range Management, 40: 542546.

Van Soest, P.J., Robertson, J.D. \& Lewis, B.A. (1991). Methods for Diatery Fibre, Neutral Detergent Fibre and Non-Starch Polysaccharides in Relation to Animals Nutrition. Journal of Dairy Science, 74: 35833597. 